\title{
Improvement on Rights Protection of Criminals of Death Penalty in China
}

\author{
Bing Zou ${ }^{1}$ \\ ${ }^{1}$ School of Law, Southwest University, Chongqing, China \\ Correspondence: Bing Zou, School of Law, Southwest University, Chongqing 400715, China. E-mail: \\ Zblaw99@163.com
}

Received: February 26, 2012

Accepted: March 21, $2012 \quad$ Published: July 1, 2012

doi:10.5539/ass.v8n8p40

URL: http://dx.doi.org/10.5539/ass.v8n8p40

\begin{abstract}
Death penalty is developing towards the direction of humanity in a global sphere, but guarantee of rights of criminals of death penalty in China still has a lot of problems. Quite a lot of rights of criminals of death penalty are the most fundamental human rights and have profound theoretical foundation. China ought to establish and strengthen the following rights of criminals of death penalty, such as, right of claim for absolution, reproductive right, right of cohabitation with the spouse prior to death, right of personality, right of psychological guidance, right of terminal care, right of choosing the implementation modes of carrying out the humanized death penalty and right of disposal of their organs and corpse prior to death, etc.
\end{abstract}

Keywords: criminals of death penalty, rights, protection, improvement

\section{Humanized Development of Death Penalty and Predicament of Protection on Rights of Criminals of Death Penalty in China}

For the time being, more than half of countries and regions in the world have abolished death penalty. Due to the social development level of China and the value concepts of Chinese people, it determines that it is unlikely to abolish death penalty within a short period of time. Furthermore, compared with other countries in the word that still retain death penalty, China is a country that has most provisions on charges of death penalty in the world (Tian Wenchang \& Yan Jiuhong, 2005). It has become a mainstream penalty idea to guarantee human rights of criminals of death penalty, humanize execution of death penalty and reduce execution of death penalty in a painful mode. In countries and regions which still retain death penalty, all the rights of criminals of death penalty prior to death have aroused wide attention. For example, in states of US where death penalty still remains, there are the five death penalty execution modes for the criminals of death penalty to choose, namely, execution of death penalty by shooting, electrocution, poison gas, death by hanging and injection. In the small number of death penalty execution cases in US, the mode of injection is chosen almost in all the cases. As for specific rights of criminals of death penalty, laws in a lot of countries have quite humanized stipulations, such as, allowing the relatives, friends and lawyers to visit the criminals of death penalty regularly and criminals of death penalty allowed to hold a conversation with their relatives and friends. Some prisons also allows for "touch visit", in which the criminals of death penalty may converse and touch with their relatives and friends with freedom and without any barrier through an isolation strip, including dining and entertaining, etc. Before the death penalty is carried out, the criminals of death penalty may spend their last time with their families in the death row and have a final farewell dinner with their families, and some criminals of death penalty may even have the right of cohabitation with their spouse prior to death. As for those criminals of death penalty who have a religious belief, they may be given religious care in the process of executing the death penalty and there is usually a priest or a minister before the death penalty is carried out to pray for them and give them religious rites. Before an electrocution or a poison gas penalty is executed, the executors would ensure the criminals of death penalty that the execution would be successful and without any pain, give them spiritual comfort and alleviate their tense emotion, which all contain humanistic concern for the criminals of death penalty. In addition, the international community also promulgates a series of covenants to protect the legal rights of interests of criminals of death penalty and offers international standards for implementation of humanitarism of death penalty. It is clearly stipulated by the United Nations in "Safeguards guaranteeing protection of the rights of those facing the death penalty", "After one is sentenced to death, the execution of death penalty should try to relieve his pain." It is 
stipulated in Article 7 in "International Covenant on Civil and Political Rights", "No one should be given any cruel torture or given any cruel, inhuman or contumelious treatment or penalty." China has already signed a series of international covenants on human rights and has made a solemn promise about guaranteeing human rights that it will realize protection on legal rights and interests of criminals of death penalty in the national law in strict accordance with the spirit of the covenant.

With development of the society, the attitude of China towards criminals of death penalty has undergone a development process of antipathy --- sympathy --- concern. In the traditional Chinese society, the concepts were deeply rooted that a crime was hated, a crime was presumed, a crime was punished and a criminal was punished. In the tradition that was deficient of rights security and the law pursued a perfect social order and emphasized obligation orientation, people generally had a mind of hating the criminals and punishing the criminals. On that basis, formulation of a criminal penalty was aimed at revenge, retribution and punishment. It was generally thought that the criminals of death penalty had already seriously violated rights of others, and there was no human right for the criminals of death penalty. Thus, execution of death penalty in the last century was deficient of enough humanized care. Especially at the era of "prohibition", a judgment was pronounced in public to the criminals of death penalty, the criminals were led through the streets to warn the public and then were executed by shooting, which were almost an indispensable procedure for a large majority of death penalty cases. Human rights of criminals of death penalty were totally a strange concept that the social public were unlikely to accept. At the beginning of the $21^{\text {st }}$ Century, the human rights campaign got vigorous development in the judicial field. Especially with development ever since the reform and opening up of China for over thirty years, politics, economy, culture and concepts in Chinese society had taken earthshaking changes and the human rights security in China had obtained long term development, when the human rights security of criminals of death penalty began to arouse attention of the whole society. In 1997, the mode of injection appeared in China to execute death penalty, which was the beginning of humanized death penalty in China. Afterwards, different local courts began to gradually explore some humanized practices, such as, allowing criminals of death penalty to meet with their family members, arranging appropriately the diet of criminals of death penalty and assisting criminals of death penalty in making a will, etc. Some measures have ascended to the legal level after effective exploration for several years and have been applicable in the whole country. In 2007, the Supreme People's Court, the Supreme people's Procuratorate, Ministry of Public Security and Ministry of Justice jointly promulgated "Opinions on Strengthening Handling Cases in Strict Accordance with Law and Guaranteeing the Quality of Handling Death Penalty Cases", which emphasized a focus on guaranteeing the basic rights of criminals of death penalty. However, as a whole, especially compared with guarantee of the international society of human rights of criminals of death penalty, China still has an obvious gap. At present, the following three problems are relatively prominent. In the first place, a high level legislation and a perfect system provision are lacking for guaranteeing rights of criminals of death penalty and the local areas act differently in practice and each does as they wish. The international covenant which China has participated in has not been well implemented due to deficiency of the national law. In the second place, restrained by funds or affected by the traditional concepts, quite a lot of local juridical organs ignore the ultimate basic human rights of criminals of death penalty and even the demand of criminals of death penalty to meet with their family is unlikely to be satisfied. All kinds of speculations, reports and denouncements about abuse of corpses and organs of criminals of death penalty lingered in our ears, which seriously affected the judicial image and the human rights guarantee in China. In general, the overall level of guarantee on human rights of criminals of death penalty in China is still low. In the third place, some new problems emerge in practice about guarantee on rights and interests of criminals of death penalty, such as, reproductive right and right of absolution with the spouse of criminals of death penalty, which lead to a dispute and even appeal to the court. However, due to lacking in evidence of solution, the court may often feel at a loose end in hearing the cases and the "vacuum zone" may appear that "there is no law to abide by". Thus, it is urgently required to make a legislation to define the rights of criminals of death penalty.

\section{Theoretical Foundation for Protection on Rights of Criminals of Death Penalty}

Human rights are the basic rights that a person is supposed to share and whether one is able to share the human rights, the primary judgment standard is whether the subject is a person, but not requirements of other aspects of the subject (Tong Zhiwei, 2004). The core of human rights is to regard a person as a person and to give him treatment and care of a person. Although those citizens who have violated the law, committed a crime or been of guilt have been deprived of some legal rights in accordance with the law, it doesn't mean that all their rights have been deprived, as each person as a member of the society is entitled to have such basic human rights as subsistence right, development right, freedom rights and equality right as a person. First of all, a criminal of death penalty exists as a person, so he is supposed to enjoy all the basic rights that a person should. 
Humanitarism to a criminal of death penalty is not extra award by the country and the society to the criminal of death penalty, but the requirement of the essential attribute of human rights.

Criminals of death penalty are deprived of right of life and relevant rights in accordance with the law as they have committed a crime. According to "Criminal Law" in China, those criminals who have been sentenced to death also have to be deprived of the political rights for all their life. Deprivation of the political rights refers to deprivation of the following several rights: the right to vote and the right to be voted, the right of freedom in speeches, publication, assembly, association formation and marching, the right to hold a function in the state organs and the right to hold a leadership function in state-owned companies and enterprises, public institutions and people's organizations. Now that the law only deprives the criminals of death penalty of their right of life and the above rights, it has not clearly deprived them of other rights. Thus, the law has to guarantee the basic rights of criminals of death penalty that they are entitled to share as an individual of life. In addition, some basic human rights, such as, personality right, are closely connected with the life and if the life does not cease, the rights are supposed to exist simultaneously. However, since the criminals of death penalty are in custody and are going to be deprived of life, fulfillment of their rights will necessarily be different from that of the ordinary people, and many of their human rights may be restrained, such as, right of marriage, reproductive right, right of personality and so on. In the logical structure, the rights of criminals of death penalty can be classified into three levels, namely, the rights that the criminals of death penalty are entitled to as a natural person, the rights that the criminals of death penalty are entitled to as a citizen and the rights that the criminals are entitled to as a criminal.

\section{Improvement on Rights Protection of Criminals of Death Penalty in China}

China should decide rationally the rights scope of criminals of death penalty within the basic framework defined for rights of criminals of death penalty according to the social material and technical conditions and the ideological and cultural development level of the society and guarantee fulfillment of rights of criminals of death penalty.

\subsection{Right of Claim for Absolution}

Claim for right of absolution among criminals of death penalty has been stipulated in a number of international covenants. It is stipulated in Item Four of Article Six in "International Covenant on Civil and Political Rights" by the United Nations that, "Anyone who is sentenced to death is entitled to claim to absolve or reduce a penalty and any case of death penalty can be considered for a general pardon, a special pardon or an abatement from penalty." The system of absolution has been of long standing and in the modern legal society, it has changed from a benediction by the king to a criminal policy to adjust social conflicts and make up for legal disadvantages. The whole world attaches great importance to application of the system of absolution. Nevertheless, there is no stipulation on general pardon in the constitution in China, but only the system of special pardon. Ever since China was founded, it had implemented the special pardon for seven times. However, in the past thirty years, the system of absolution has been set aside formally, and the deserved value of the system has not yet function at all. As the group of people who are most in the need of being relieved, criminals of death penalty are supposed to be endowed with the right of claim for absolution. One more investigation procedure not only guarantees the solemnness and cautiousness of death penalty, but also helps to avoid occurrence of any unjust case without malice. China signed "International Covenant on Civil and Political Rights" in 1998, which was also the requirement for China to perform its international obligations.

\subsection{Reproductive Right}

Reproductive right is an instinctive and natural right of human beings. Reproductive right has derived as the personality right of citizens and appears in the body of basic laws and important international covenants in some countries as a right that a natural person is entitled to share after birth. In 1968, the United Nations, for the first time, acknowledged the reproductive right as a basic human right. Likewise, the reproductive right was stipulated as a personal right in "Mexico Manifesto about the Equal Standing of Women and Their Contribution to Development and Peace" that was issued on July 3, 1965 and in "Programme of Action about International Conference on Population and Development" that was issued in 1994, emphasizing that the reproductive right of anyone should be respected and indicating the international appeal to bring the reproductive right into the right of personality. It is also clearly stipulated in Article 17 in "Law of Population and Family Planning of the People's Republic of China", "A citizen has the reproductive right and also has the obligation to put family planning into practice in accordance with the law". Thus, it can be seen that, the subject of reproductive right is "citizens" which, of course, include the criminals of death penalty who have not been executed the death penalty and their families. Development of modern assisted reproductive technology also offers technical conditions for fulfillment of the reproductive right of criminals of death penalty. 


\subsection{Right of Cohabitation with the Spouse Prior to Death}

Allowing the criminals who are serving a sentence to cohabit with their spouses visiting them in the prison has been a custom in western countries. Sweden, US, the Netherlands and Taiwan all have relevant system regulations that allow the criminals to cohabit with their spouses, not including the criminals of death penalty, such as, the system of "living together with family dependants" in Taiwan (Liu Zhongwei, 2008). In practice, China has also gradually fulfilled the right of cohabitation of criminals in custody with their spouses. For instance, "preferential meeting room" is set up in Nanjing prisons to allow the couples to cohabit and Beijing women prison offers the meeting mode of cohabitation with their spouses for those serving a sentence who have had good performance in all aspects and applied for cohabitation. However, it has never happened in practice whether criminals of death penalty are entitled to enjoy the right of cohabitation with their spouses. As a matter of fact, the right of cohabitation among criminals of death penalty is the content of the right of marriage and is the basic guarantee of the reproductive right, which both belong to the basic human rights of criminals of death penalty. Thus, respect and even protection on the cohabitation right of criminals of death penalty is humanization of a criminal penalty and is also the requirement of socialization of a criminal penalty.

\subsection{Right of Personality}

Personal dignity is recognition and respect of a citizen for the personality value or social value of his own or others based on the objective conditions of the social environment, status, reputation, working atmosphere and family relationship of the citizen (Wang Liming, 1997). Right of personality is inherent and should not be deprived. Right of personality is as precious as the life and some people even believe that personality dignity is more important than life. Death penalty is a negative assessment on the criminal behaviors, but it should not deny all other rights of the criminals of death penalty. Previously, in order to strengthen the deterrent function of death penalty, the local judicial organs would hold a judgment pronouncement rally before a death penalty was carried out. In the rally, the criminals of death penalty were tied with their hands behind their back. They were led through the streets to warn the public and then sent to the execution ground to execute the death penalty together. The criminals were seen as a tool and a means, not a person and that had seriously violated the personality dignity of criminals of death penalty and also had greatly injured feelings of the family of criminals of death penalty. Protection of personality dignity of criminals of death penalty shows respect of human being for the life. The Chinese criminal laws have to strengthen relevant legislation, show respect for personality dignity of criminals of death penalty and let them end their life in a decent way.

\subsection{Right of Psychological Guidance}

From the first instance to the second instance and until re-examination, death penalty in China takes a long period of time. During the last long-drawn-out period of time in their life, the criminals of death penalty and their family members endure fear, pain and uneasiness which the ordinary people are unlikely to imagine and some criminals of death penalty are even, thereby, distorted and collapse. At this time, if criminals of death penalty are provided with psychological counseling and rectification, their fear of death might be alleviated. Psychological counseling should not be seen as benevolence of the national judicial organs for criminals of death penalty, but is the obligation and responsibility of national judicial organs, so it should be institutionalized. Prior to death, the criminals of death penalty are supposed to be informed of the time, place and mode of death for execution of death penalty so as to let them make preparations in terms of thought and make arrangements for what will happen after their death. Common criminals of death penalty have to be provided with psychological counseling, while criminals of death penalty with religious beliefs should be given a simple religious farewell ceremony by the church that they belong to, so as to try to alleviate fear of criminals in death and make them finish the ultimate life path peacefully and effortlessly.

\subsection{Right of Terminal Care}

"Terminal care" is originally a concept in medical science, which means that the whole society shows care for the endangered patients and their family members so as to make the patients spend the final life in a comfortable and enjoyable way. So far, the value of this concept has gone beyond the medical scope. Criminals of death penalty can be said to be a particular abominated "endangered patient" and we have to get rid of this discriminatory concept and show care for this terminal life, such as, preferential treatment with the ultimate daily life and material conditions of criminals of death penalty, meeting their will prior to death, diminishing their worries after death and allowing criminals of death penalty to meet with their family members and even live together temporarily. All these terminal cares not only comfort the criminals of death penalty, but also alleviate sorrow of their relatives and friends and any hatred that might be triggered, and has received perfect social effects 


\subsection{Right to Choose a Humanized Death Penalty Execution Mode}

Execution of death penalty has been transited little by little from the cruel and barbaric modes at the very beginning to such civilization modes of execution by shooting, electric chair and injection, etc. It is also stipulated in "Code of Criminal Procedure" that, execution of death penalty should use the modes of execution by shooting and injection, etc. Compared with execution by shooting, apparently, injection is more likely to reduce pain and fear of criminals of death penalty and can effectively diminish the spiritual injury caused on family members of criminals of death penalty, so it is a more scientific and civilized death penalty execution mode. However, as the cost of execution of injection is too high at present and the procedures are too complicated, the proportion of its adaptability in China is still low even if it has been one of the death penalty execution modes in China for more than a decade. Respect for the will of criminals of death penalty and diminishing pain of criminals of death penalty suffered in the process of death penalty execution is an important reflection of humanization of execution of death penalty. With continuous improvement of the procedures, China has to increase the adaptability proportion of injection, endow criminals of death penalty with the right of selection for their death penalty execution mode under the circumstance that multiple modes of death penalty execution exist and show respect for choice of criminals of death penalty in execution of their death penalty.

\subsection{Right of Disposal of Organ and Corpse Prior to Death}

Disposal of criminals of death penalty of their organs and corpses and keeping their corpses intact and complete is an important right of criminals of death penalty. In this regard, it can be said that legislation in China is still in its blankness. On one hand, some local criminals of death penalty intend to donate their organs, but they are often refused due to lack of a legal evidence, so they are unlikely to fulfill the will of resipiscence and returning on the society. On April 20, 2010, human organ donation experimental work in Guangdong emphasized that the current human organ donation experimental work scope was confined to donation of corpses and organs of the social public, but did not concern with donation of corpses and organs of criminals of death penalty. On the other hand, organs of some local criminals of death penalty are illegally abused, which arouses hatred of family members of death penalty. Criminals of death penalty are entitled to the right of disposal of their own corpses in accordance with their own will. Thus, the $14^{\text {th }}$ representative assembly of the International Association of Penal Law clearly stipulated in "Agreement about the Problem of Penal Law and Modern Biological and Medical Technology", disposal of corpses of criminals of death penalty by any country ought to secure the agreement of criminals of death penalty or their family members and show respect for local customs and habits. Legislation has to set up standardized procedures to guarantee fulfillment of this right of criminals of death penalty so as to resolve the current condition that corpses of criminals of death penalty are unlikely to be disposed.

\section{References}

Liu, Zhongwei. (2008). Proprietary Right of Criminals. Studies in Law and Business, 4.

Tian, Wenchang \& Yan, Jiuhong. (2005). On Development Trend of Death penalty in China. Contemporary Law Review, 2.

Tong, Zhiwei. (2004). Value of Human Rights Brought into the Constitution. Jurists Review, 4.

Wang, Liming. (1997). Right of Personality. Law Press, 35. 